\title{
Relationship between seepage water volume and total suspended solids of landslide dam failure caused by seepage: an experimental investigation
}

Prakash Dhungana* and Fawu Wang

\begin{abstract}
Background: Landslide dams inevitably demonstrate the potential for catastrophic failure with high-risk damage to life and property at the downstream site. Hence, knowledge of the internal stability of dam materials is a key to predicting the seepage failure of landslide dams. In this study, experiments were conducted to examine the relationship between seepage volume and total suspended solids (TSS) of seepage water based on hydro mechanical constrains. Understanding the relationship between the seepage volume and TSS with hydro-mechanical constraints supports the prediction of the seepage failure of landslide dams at the field level.

Result: Experiments were conducted with a mixed sample of silica sands. Seepage water was collected from a flume tank with the facility to measure the hydraulic gradient, vertical displacement, and seepage water volume. Grain size affected the life span of the dam. The seepage volume increased with the increase in the percentage of silica sand S4, whereas TSS increased with the increase in the percentage of silica sand S8. With the increase in the dam height, the dam life decreases for low coeficient of uniformity of the grain size distribution. With the increase in the reservoir size, TSS decreased, and the total seepage volume increased.

Conclusion: Dam failure depends on the particle size, dam geometry, inflow rates, reservoir size, hydraulic gradient, and seepage water volume, and TSS of seepage water. The results indicated that with the increase in fine particles, the life span decreases, and TSS increases. With the increase in the flow rate, the dam life span decreases, and the TSS and seepage volume rate increase.The dam height leads to an increase seepage volume with low TSS, where the life span of the dam also depends on the particle size distribution With the increase in the reservoir size, the seepage water volume decreases with low TSS.
\end{abstract}

Keywords: Landslide dam, Seepage volume, Hydraulic gradient, Total suspended solids (TSS), Inflow rate, Dam height

\section{Introduction}

Formation and failure of landslide dams in mountainous areas constitute a significant natural hazard. A majority of landslides that block rivers are either caused by heavy rainfall or earthquakes (Schuster and Costa, 1986; Canuti et al., 1988; Costa and Schuster, 1988; Korup, 2004; Evans et al., 2011; Peng and Zhan, 2012; Casagli et al. 2003; Tacconi et al., 2018). As the landslide mass shifts from its original position to the river,

\footnotetext{
* Correspondence: civildhungana@gmail.com

Department of Earth Science, Shimane University, 1060 Nishikawatsu-Cho, Matsue, Shimane 690-8504, Japan
}

\section{Springer Open}

it may contain debris and loose soils. Hence, a landslide dam is composed of heterogeneous or poorly consolidated material with debris. A landslide dam differs from a constructed embankment dam as it exhibits no control structure for seepage and drainage (Uhlir, 1998; Awal et al., 2007). A better understanding of premonitory factors, which can easily be measured or observed in actual landslide dams that are at high risk of failure, is crucial for disaster reduction (Wang et al., 2018). In real fields, due to the high risk of failure, limited parameters such as seepage quantity, turbidity of downstream seepage, vertical displacement of the dam crest, 
reservoir level, and impounded area can be monitored (Dhungana and Wang, 2019).

The inflow rate into the reservoir and reservoir volume, dam size, and dam material are important factors that affect the failure of a landslide dam (Schuster and Costa, 1988). Some authors already reported the statistics of landslide dams and their failure in various regions worldwide. They have summarized the important characteristics of landslide dams including their classification, cause and type of failure, life span, and some other important parameters (Costa and Schuster, 1991; Korup, 2004; Stefanelli et al., 2015; Xu et al., 2009; Casagli and Ermini, 1999; Chai et al., 1995; Clague and Evans, 1994).

Overtopping, piping, and seepage failure constitute the typical failures of landslide dams. Dams comprising homogeneous soil mostly undergo failure by seepage and downstream slope saturation (Dunning et al., 2006), whereas piping holes are formed in dams that are built with mixed soil, depending on the percentage of the fine content and the interlocking bond between soil particles.

Failure sequence of a dam was reportedly categorized into four periods: 1) emergence of seepage water and front wetting, 2) hyper-concentrated flow discharge, 3) emergence and development of a dam crest, and 4) failure of a dam crest with a sharp increase in its subsidence (Wang et al., 2018). Dhungana and Wang (2019) described the conditions for the failure and stability of the landslide dam for seepage failure, where trends of total suspended solids (TSS) and the hydraulic gradient were compared under failure and stable conditions.

Internal instability is a failure mode of soil subjected to seepage. The seepage failure mode is characterized by the erosion of fine particles through the pore matrix of the coarse fraction of the soil (Richards and Reddy, 2007). Due to the erosion of fine particles, the flow path undergoes expansion, leading to the resistance strength loss of the external load (Ahlinhan et al., 2016).

In addition, TSS supports the understanding of the dam material erosion. Turbidity and TSS are identical premonitory factors that can be measured under field and laboratory settings (Rugner et al., 2013; Stubblefield et al., 2007). Fine particles, which are among coarser grains, are almost free from effective overburden and it can migrate under an extremely-low-velocity seepage flow (Takaji et al., 2008). Such eroded particles can be measured as TSS in the laboratory and in the field (Dhungana and Wang, 2019).

Several studies (Rinaldi and Casagli, 1999; Lobkovsky et al., 2004; Wilson et al., 2007; Fox et al., 2007) reported detailed research on seepage erosion for slope failures. Numerous experimental methods were used to simulate the development of internal erosion in earth dams and landslide dams (Wit et al., 1981; Brauns, 1985; Maknoon and Mahdi, 2010; Wang et al., 2018; Okeke et al., 2016a, 2016b). Hanson et al. (2010) analyzed the variation in the erodibility of different soil materials due to the internal erosion of dams by large-scale outdoor model tests. They observed that the rate of erosion in different soil materials varies in order of magnitude.

Chang et al. (2011) conducted field erodibility tests on two landslide dams triggered by the 12 May 2008, Ms. 8.0 Wenchuan earthquake in the Sichuan Province of China and revealed that an increase in the bulk density is inversely proportional to the coefficient of erodibility with depth. Furthermore, Hanson et al. (2010) conducted large-scale physical tests to investigate the impact of erosion resistance on internal erosion in embankment dams and revealed that erosion resistance for the same embankment material increases with the increase in the compactive effort and water content.

Many studies have been conducted on different landslide dam failures, possibly overtopping, piping, and seepage (Awal et al., 2007, 2011; Wang et al., 2018). However, a majority of these studies highlighted failure patterns, while only limited studies focused on the seepage failure and internal erosion. In addition, effects on the turbidity, seepage volume, and failure mechanism with different parameters of landslide dams were not examined.

Hence, this study aimed to highlight the relationship between the seepage volume and TSS of landslide dams during failure. In this case, the hydraulic gradient was measured using pore-water pressure sensors; vertical displacement was measured using a laser sensor at the dam crest; seepage water was collected, and seepage volume was monitored using a porewater pressure sensor. A seepage water sample was collected, and TSS was measured.

\section{Methods \\ Experimental setup}

In the laboratory, a flume tank with $0.45 \mathrm{~m}$ height $\times$ $0.45 \mathrm{~m}$ width $\times 2.0 \mathrm{~m}$ length was prepared for the experiment. On the downstream side of the flume tank, the flow of seepage water was stopped and diverted into a tank using holes at a distance of $0.75 \mathrm{~m}$ from the dam center (Fig. 1). Experimental studies of the flume tank were performed for the selection of a dam size, including the $1 \mathrm{~m} \times 0.6 \mathrm{~m} \times 0.45 \mathrm{~m}$ model used by Sidle et al. (1995), $5 \mathrm{~m} \times 0.3 \mathrm{~m} \times 0.5 \mathrm{~m}$ model used by Awal et al. (2007), $1.5 \mathrm{~m} \times 1 \mathrm{~m}$ model used by Wilson (2009), 1.4 $\mathrm{m} \times 1 \mathrm{~m}$ model used by Wilson (2011), and $0.5 \mathrm{~m} \times 0.5$ $\mathrm{m} \times 0.5 \mathrm{~m}$ model used by Fox et al. (2014). In this study, the dam heights were $0.2 \mathrm{~m}$ and $0.25 \mathrm{~m}$, and upstream and downstream slopes were $45^{\circ}$ and $35^{\circ}$, respectively. 


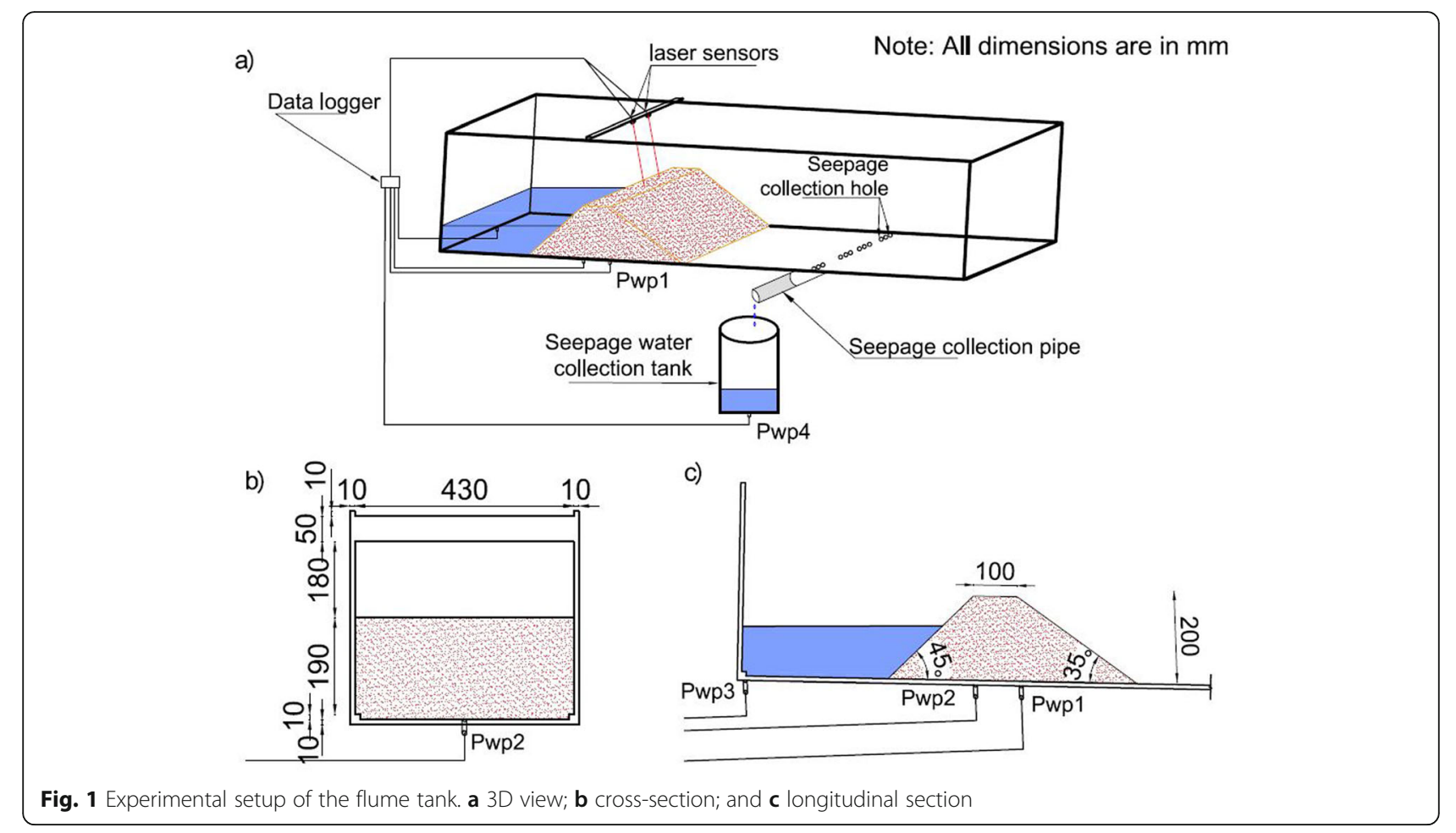

The dam height was increased from $0.2 \mathrm{~m}$ to $0.25 \mathrm{~m}$ whereas the downstream and upstream slopes were constant, and the dam volume was also increased due to height increase. Similarly, in the flume tank, the position of the dam was shifted downstream side by $0.1 \mathrm{~m}$ to increase the reservoir size. The width of dam crest was $0.1 \mathrm{~m}$. On the floor of the flume tank, a double-sided tape was used, and dry silica sand 6 was poured over it to maintain the roughness between the dam material and flume tank floor. The flume tank was built using Plexiglas, permitting visibility into the flume. The flume bed slope was maintained constant at 1:20 during all experiments. Four pore-water pressure sensors, with a rated capacity of $50 \mathrm{kPa}$, were used-hereafter referred to as Pwp1, Pwp2, Pwp3, and Pwp4-for the downstream and upstream sides of the dam body and at the reservoir and seepage water collection tank, respectively. Sensors Pwp1, Pwp2, and Pwp3 were connected to the flume tank from the base of the flume tank facing upwards. Pwp1 and Pwp2 were covered by the filter material to control the flow of sand over it. The Pwp4 sensor was connected to the tank base, where seepage water was collected. Multi-function analog laser sensors (CMOS) were used to measure the vertical displacement from the top of the flume tank using a wooden frame-hereafter known as $\mathrm{Vdr}$ and $\mathrm{Vdl}$, for the right and left sides, respectively. The vertical displacement of the dam crest was continuously monitored at two fixed points by laser sensors. A half-cut polyvinyl chloride (PVC) pipe was fixed below the holes with a gentle slope to collect seepage water. The collected seepage water volume was monitored by the Pwp4 sensor.

\section{Material and method}

Typically, landslide dams comprise fragmented materials with a wide range of sediment sizes (Costa and Schuster, 1988; Schuster, 1995). It is challenging to scale down actual landslide dam material to the laboratory scale. From laboratory practice, three mixtures of artificial silica sand were selected for the experiment for seepage failure. Different proportions of a combination of silica sands S4, S5, S6, and S8 were used (Table 1). The main part of the sample was silica sands S5 and S6. Silica sands S4 and S8 were considered as coarser and finer particles, respectively, and mixed with silica sands S5 and S6. Three samples, i.e., S456, S4568, and S568, respectively, were prepared in the presence and absence of silica sands $\mathrm{S} 4$ and S8. The grain size distributions of the samples are shown in Fig. 2.

A mixing machine was used for mixing dam materials. Initially, the mixing machine was used for dry mixing, followed by mixing with water for affording the desired shape of the dam. Before creating the dam in the flume tank, a sample was collected to estimate its initial water content. In addition, sensors were placed in their respective positions, and the dam was prepared by layer- 
Table 1 Mixed ratios and mechanical properties of samples

\begin{tabular}{llllllllll}
\hline Sample number & SS 4 (kg) & SS 5 (kg) & SS 6 (kg) & SS 8 $(\mathrm{kg})$ & Water $(\mathrm{kg})$ & Total $(\mathrm{kg})$ & $\begin{array}{l}\mathrm{D}_{50} \\
(\mathrm{~mm})\end{array}$ & $C_{u}$ & $C_{c}$ \\
\hline S456 & 1 & 5 & 5 & - & 0.5 & 11.5 & 0.394 & 3.075 & 1.375 \\
S4568 & 0.5 & 5 & 5 & 0.5 & 0.5 & 11.5 & 0.565 & 2.185 & 1.098 \\
S568 & - & 5 & 5 & 1 & 0.5 & 11.5 & 0.557 & 2.264 & 1.065 \\
\hline
\end{tabular}

$D_{50}=$ median grain size; $C_{u}=$ coefficient of uniformity; $C_{c}=$ coefficient of curvature

to-layer compaction, divided into four and six parts for dam heights of $0.2 \mathrm{~m}$ and $0.25 \mathrm{~m}$, respectively. Each layer comprised $\sim 9 \mathrm{~kg}$ of sample, and 1-2 kg of sample was used to obtain the final shape of the dam. Real-time data were collected using universal recorders (KYOWA PCD 330B and PCD 400). Sampling frequency was two of data per second. A stopwatch was used during the collection of a seepage water sample for TSS. After collecting a sample for TSS, the volume was measured, followed by oven-drying at $105^{\circ} \mathrm{C}$. The dried sample weight was measured, and the TSS value was calculated. Seepage water was directly collected into a tank using the half-cut PVC pipe, and Pwp4 was used to measure the volume. The hydraulic gradient was calculated using the pressure head of two sensors, i.e., Pwp1 and Pwp2, respectively, and the flume tank slope. Pwp1 and Pwp2 were fixed below the dam crest edge downstream and upstream of the dam, respectively. The seepage volume was calculated using porewater pressure Pwp4 and tank diameter.

\section{Results and discussion}

\section{General characteristics of the experiments}

Dam failure leads to flash floods on the downstream side. Hence, it is crucial to understand the failure pattern of landslide dams to minimize natural hazards caused by floods. In this study, experiments were conducted to understand the effect of the dam height, reservoir size, and inflow rate into the reservoir on hydraulic gradient, vertical displacement, TSS, seepage water volume, and longevity of the dam for three soil samples prepared by the mix of silica sands S4, S5, S6, and S8. Table 2 summarizes the experimental details.

Time of landslide dam failure is key factor to reducing natural disasters. In this study as well, dams failed at varying periods under different conditions. The time factor plays roles in soil saturation and shear strength reduction. From experiments, the higher the percentage of silica sand S8 in the dam material, the shorter the life span of the dam. Higher the percentage of silica sand S4 in the dam material, the longer the life span of the dam. Despite this observation, a longer time was taken for the seepage water to drain out from the dam body for a sample containing silica sand S8. The density of the dam controlled the time for the initial peak hydraulic gradient, whereas density exhibited a lower effect for the total life span in contrast to the initial peak hydraulic gradient (Fig. 3).

\section{Effect of inflow rate on dam failure}

Experiments were conducted with three samples, i.e., S456, S4568, and S568, respectively, for inflow rates of $1.1 \times 10^{-5} \mathrm{~m}^{3} / \mathrm{s}$ and $1.667 \times 10^{-5} \mathrm{~m}^{3} / \mathrm{s}$. The inflow rates were selected based on practice on these samples to get

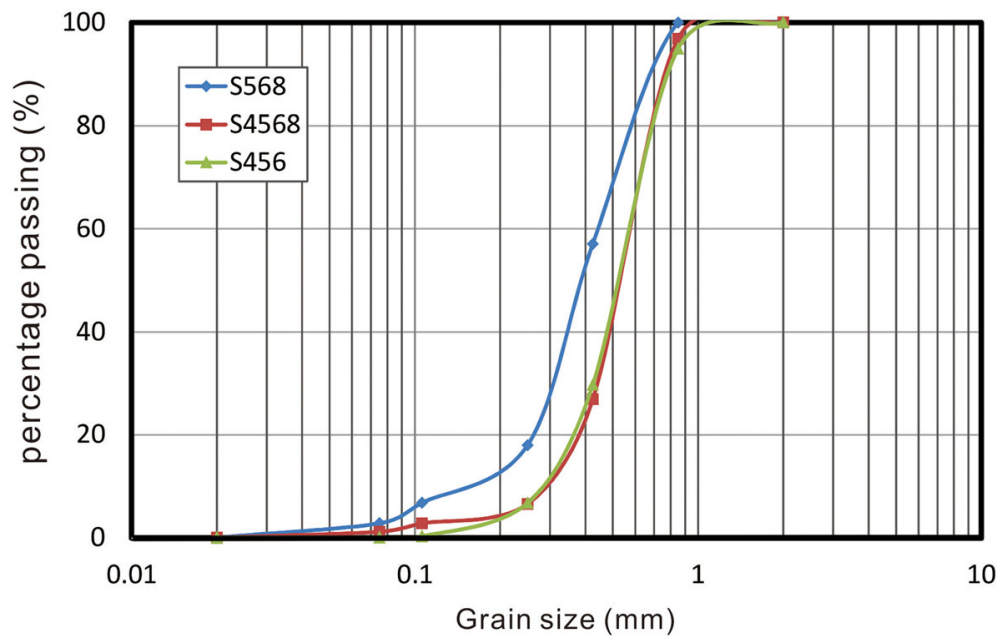

Fig. 2 Grain size distribution curves of samples used in experiments 
Table 2 Outline of all experiments under different testing conditions

\begin{tabular}{|c|c|c|c|c|c|c|}
\hline Exp. No & Sample type & Inflow rate $\left(\mathrm{m}^{3} / \mathrm{s}\right)$ & Dam height (m) & Reservoir size & Dry density $\left(\mathrm{kg} / \mathrm{m}^{3}\right)$ & Initial moisture content (\%) \\
\hline Exp1 & S568 & $1.1^{*} 10^{-5}$ & 0.2 & & 1294 & 2.7 \\
\hline Exp2 & & $1.67^{*} 10^{-5}$ & & & 1251 & 2.7 \\
\hline Exp3 & & & 0.25 & R1 & 1269 & 2.8 \\
\hline Exp4 & & & & R2 & 1223 & 3.2 \\
\hline Exp5 & S4568 & $1.1^{*} 10^{-5}$ & 0.2 & & 1334 & 2.7 \\
\hline Exp6 & & $1.67^{*} 10^{-5}$ & & & 1301 & 2.9 \\
\hline Exp7 & & & 0.25 & $\mathrm{R} 1$ & 1234 & 2.8 \\
\hline Exp8 & & & & R2 & 1241 & 2.7 \\
\hline Exp9 & S456 & $1.1 * 10^{-5}$ & 0.2 & & & \\
\hline Exp10 & & $1.67 * 10^{-5}$ & & & 1302 & 2.5 \\
\hline Exp11 & & & 0.25 & R1 & 1275 & 2.8 \\
\hline Exp12 & & & & R2 & 1202 & 3.0 \\
\hline
\end{tabular}

seepage failures. If we increase inflow rate, the dam failure type changed to overflow and if we decrease the inflow rate, the dam crest will not failed. Experimental results revealed a time lag between the peak hydraulic gradient (which is responsible for the start of seepage) and seepage flow out time (referred as TSS starting time in figures). Inflow rates into the reservoir created variations in the hydraulic process for different soil types. For the S568 sample, the initial peak hydraulic gradient that started seepage was varied from 0.29 to 0.39 (Fig. 4). In case of the higher inflow rate, the hydraulic gradient was decreased from its peak value of 0.39 to 0.23 , and again started to increase, and the dam crest underwent failure when it reached 0.28 . For the low inflow rate, the hydraulic gradient decreased from its peak value of 0.29 to 0.21 and again started to increase and undergo failure when it reached 0.39 . The rapid increment in the hydraulic gradient initiated the high seepage gradient, leading to the early flow of seepage and shear strength reduction of the dam material. This result in turn led to the high TSS and dam crest settlement. The rapid increase in the hydraulic gradient supported the erosion of soil particles from the dam body, while the seepage volume was comparatively low.

For the S4568 sample, the initial peak hydraulic gradients were 0.26 and 0.27 for low and high inflow rates, respectively, and at the time of failure, the corresponding values were 0.39 and 0.38 (Fig. 5). For the high inflow rate, the total volume of seepage water was lower, and the TSS value was high, related to the higher rate of seepage water released from the dam body. With the increase in the percentage of silica sand S4, the TSS value decreased for both inflow rates; however, the time taken for failure increased with the increase in the percentage of silica sand S4. For the S456 sample, no failure was observed at an inflow rate of $1.11 \times 10^{-5} \mathrm{~m}^{3} / \mathrm{s}$. The pore water pressure at Pwp2 and Pwp3 became constant after $8000 \mathrm{~s}$, and hence considered as the stable case, whereas for an inflow rate of $1.67 \times 10^{-5} \mathrm{~m}^{3} / \mathrm{s}$, failure was
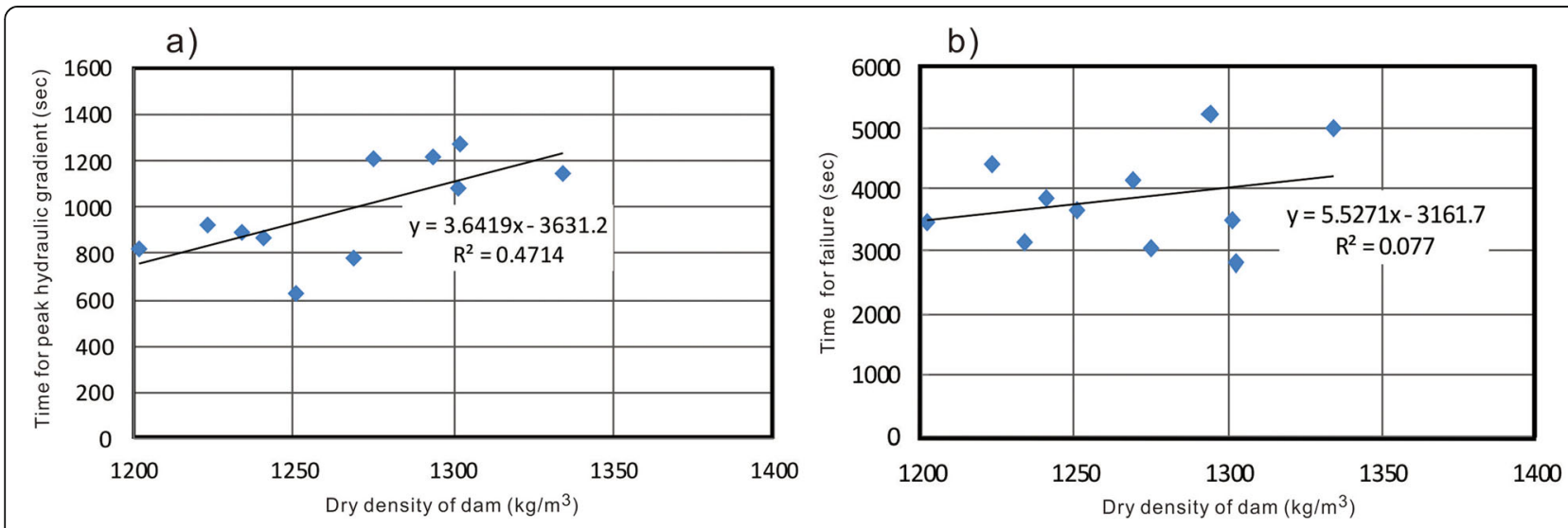

Fig. 3 Effects of density on (a) time for initial peak hydraulic gradient and (b) time for failure of dam crest 
a)

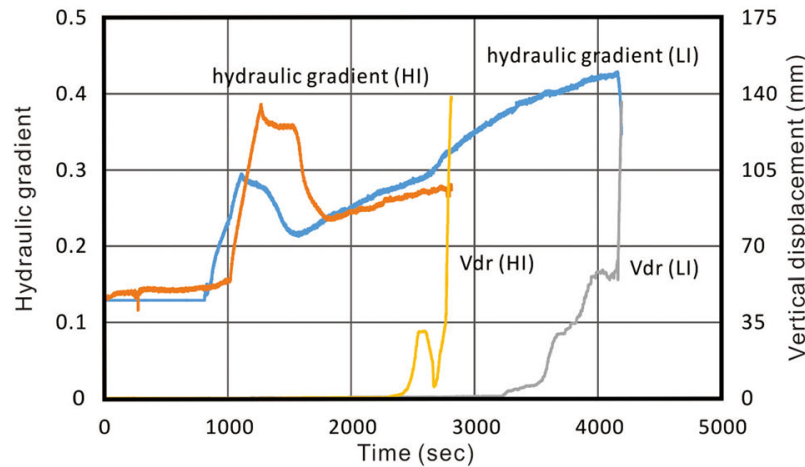

b)

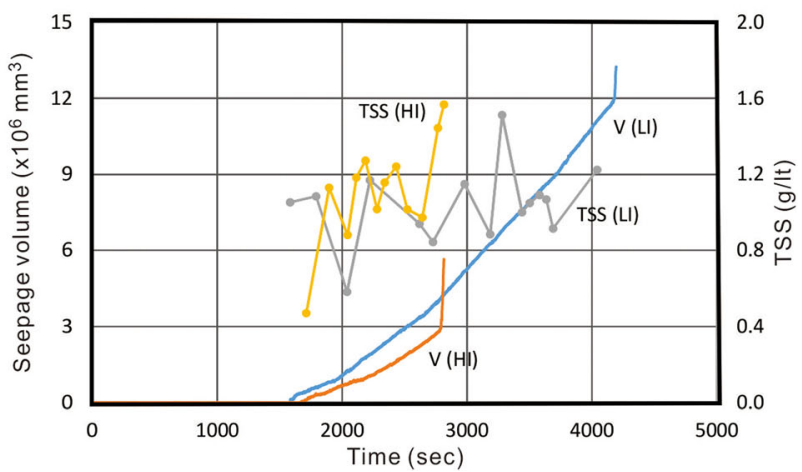

Fig. 4 Time series data of hydraulic gradient, vertical displacement, seepage volume and TSS for the sample S568 at a low inflow rate (LI) of $1.1 \times 10^{-5} \mathrm{~m}^{3} / \mathrm{s}$ and high inflow rate $(\mathrm{HI}) 1.67 \times 10^{-5} \mathrm{~m}^{3} / \mathrm{s}$. a Hydraulic gradient and vertical displacement; $\mathbf{b}$ Seepage volume and TSS

observed within $3700 \mathrm{~s}$. The seepage water flow at the lower inflow rate became extremely high, leading to a stable dam crest, whereas the TSS and vertical displacement were constant as reported by Dhungana and Wang (2019). At a high inflow rate, the lowest initial peak hydraulic gradient was observed throughout the study, and the vertical displacement sharply increased before failure. At a low inflow rate, the vertical displacement increased due to cracks in the dam crest after that horizontal movement occurred and dam crest failed.

\section{Effect of dam height on dam failure}

A statistical approach proposed a dimensionless breaking index (DBI) to investigate the stability of the dam (Ermini and Casagli, 2003). This empirical relation predicted the dam stability by using the dam geometry, where the reservoir volumes and dam heights are key parameters. The landslide dam size is the major factor that contributes to the seepage erosion and slope instability. For the soil slope instability, downstream slope angles and the soil layer gradient are major factors that control the critical hydraulic gradient (Iverson and Major, 1986; Budhu and Gobin, 1996). The landslide dam height is a key parameter for examining the stability of the natural dam. The increase in the dam height reduces the stability of the dam crest (Okeke and Wang, 2016b). Experiments were conducted to understand the effect of the dam height on the stability, TSS, and seepage water volume. For the S4568 sample (Fig. 6), containing a higher percentage of coarser sand particles and increase in dam height decrease the longevity of dam, which also was in agreement with the results reported by Okeke and Wang (2018), which may be possibly related to the mass block failure in the downstream site and increased percentage of coarser particles and sample S4568 has lowest value of coefficient of uniformity. As the initial peak hydraulic gradient of the higher dam was greater than that of the lower dam, the instability of the internal structure increased, leading to higher TSS on a)

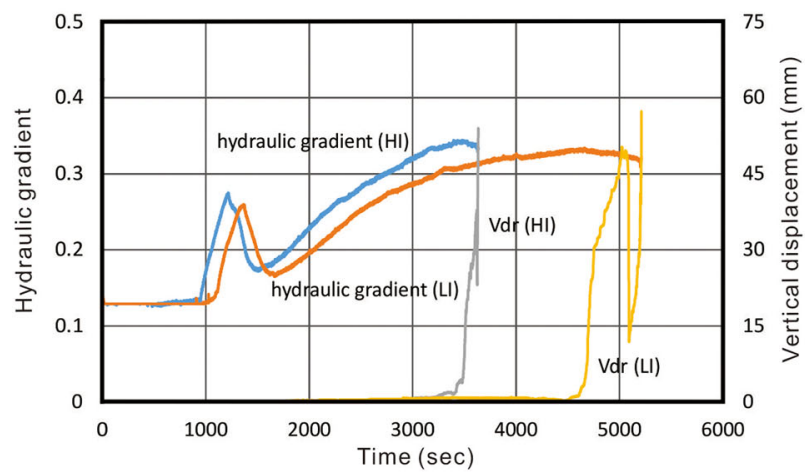

b)

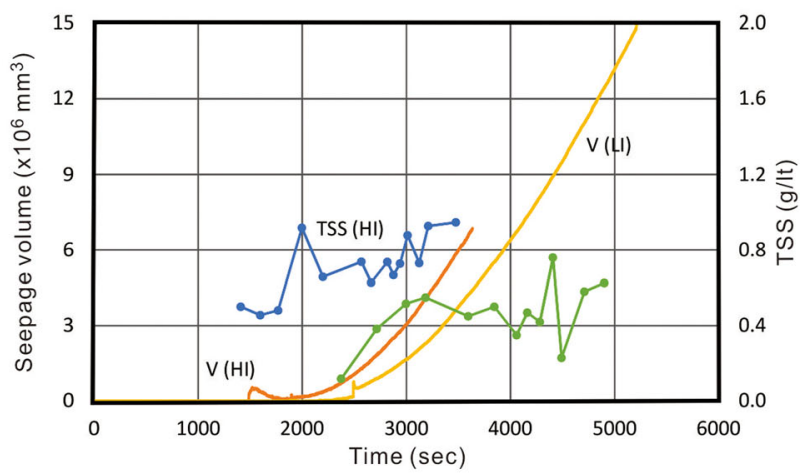

Fig. 5 Time series data of hydraulic gradient, vertical displacement, seepage volume and TSS for the sample S4568 at a low inflow rate (LI) of $1.1 \times 10^{-5} \mathrm{~m}^{3} / \mathrm{s}$ and high inflow rate $(\mathrm{HI}) 1.67 \times 10^{-5} \mathrm{~m}^{3} / \mathrm{s}$. a Hydraulic gradient and vertical displacement; b Seepage volume and TSS 


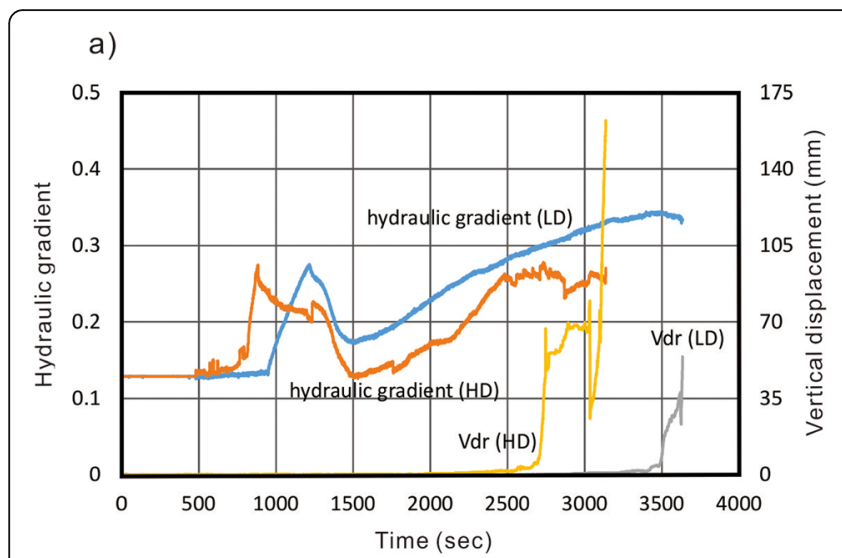

b)

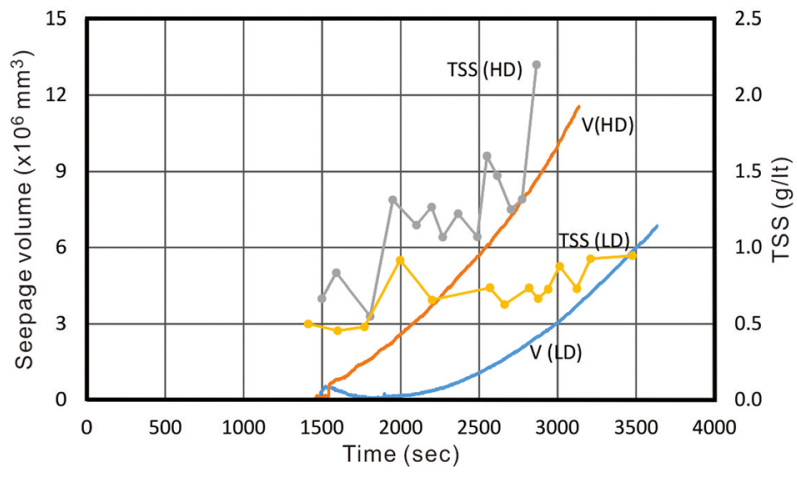

Fig. 6 Time series data of hydraulic gradient, vertical displacement, seepage volume and TSS for the sample S4568 at a Low dam height (LD) (200 mm) and High dam height (HD) $(250 \mathrm{~mm})$. a Hydraulic gradient and vertical displacement; b Seepage volume and TSS

seepage water. The seepage water volume on the downstream side increased with the dam height for all three samples. For the lower dam height, the total seepage volume was limited in comparison to that for the higher dam height within the same period. All three samples in this study revealed that the height between the reservoir water level and dam crest at the time of failure increases with the dam height; similarly, it increased with the percentage of silica sand S4; however, significant settlement in the dam crest for both cases was observed. The dam crest exhibited cracks during the test for a higher dam, and the crack size increased with the increase in the percentage of silica sand S4.

\section{Effect of reservoir size on dam failure}

Reservoir area is a leading factor in statistical analysis for proposing DBI. The static pressure caused by the river gradient to the dam body increases if the reservoir size increases. The increase in the reservoir level will increase the time for filling up the entire reservoir, which will play a role in the stability of the dam body. The reservoir size was longitudinally increased by $0.1 \mathrm{~m}$, which increased the reservoir area by $0.043 \mathrm{~m}^{2}$. The total time for the failure of the dam crest increased with the increase in the reservoir size for all three samples. The maximum hydraulic gradient for the experiment with the S456 sample was increased in comparison to those with the S4568 and S568 samples. Notably, the times for the initial peak hydraulic gradient for the S456, S4568, and S568 samples were nearly the same, whereas for a small reservoir, time for the initial hydraulic gradient increased from S456 to S568.

For the S568 sample, for the small reservoir, the hydraulic gradient was greater at the time of failure than the initial peak hydraulic gradient, and for the large reservoir, the initial peak hydraulic gradient was greater than the failure hydraulic gradient (Fig. 7). Compared to the small reservoir, a small amount of hydraulic force was observed at the initiation time of internal instability a)

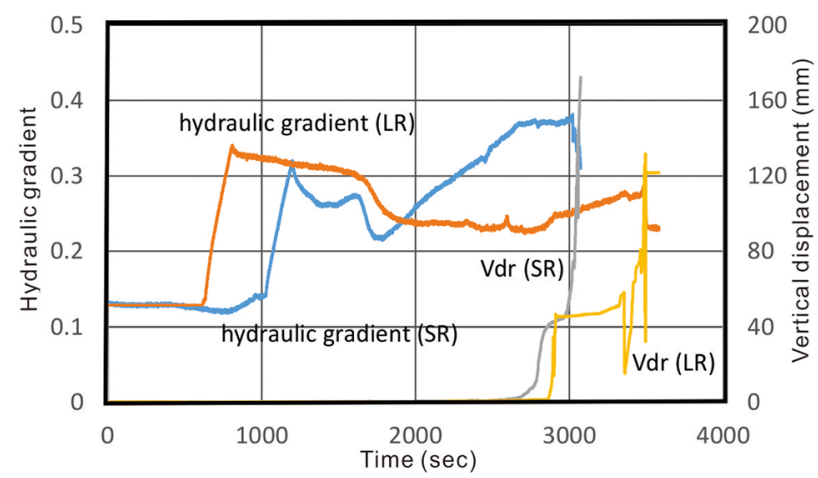

b)

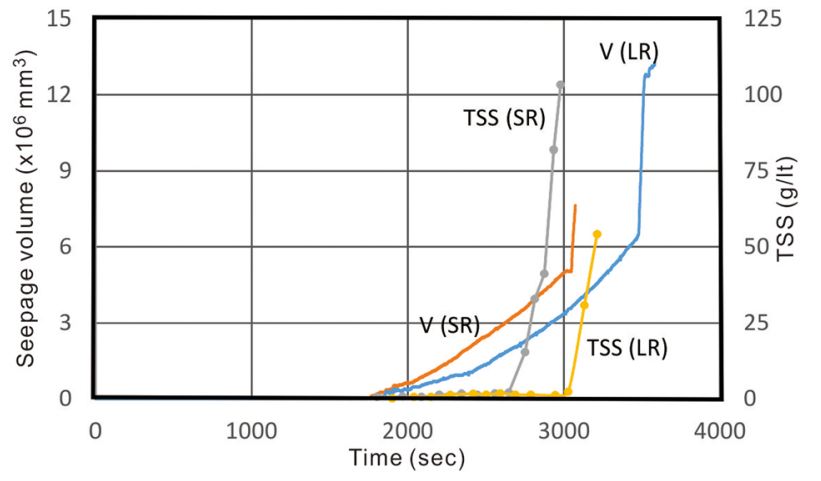

Fig. 7 Time series data of hydraulic gradient, vertical displacement, seepage volume and TSS for the sample S568 at a small reservoir (SR) and large reservoir (LR). a Hydraulic gradient and vertical displacement; $\mathbf{b}$ Seepage volume and TSS 
a)

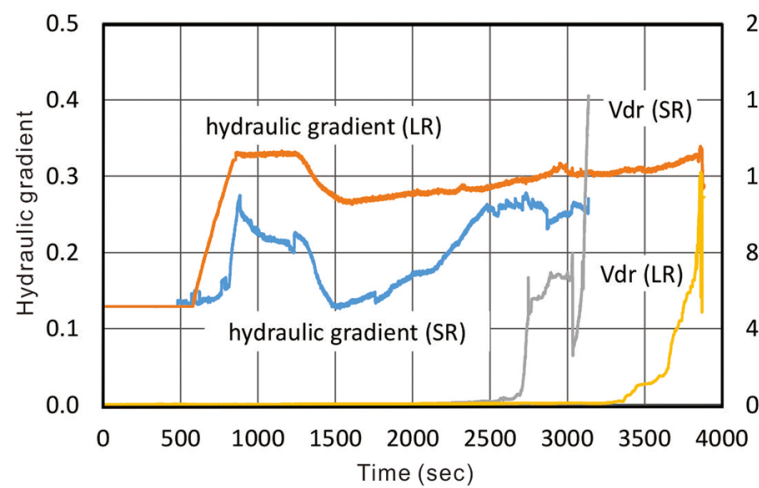

b)

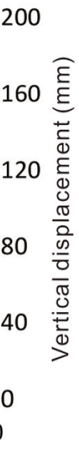

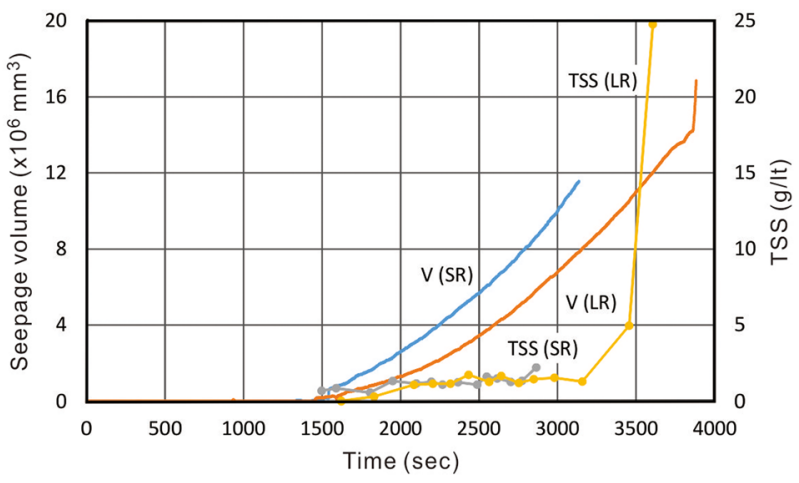

Fig. 8 Time series data of hydraulic gradient, vertical displacement, seepage volume and TSS for the sample S4568 at a small reservoir (SR) and large reservoir (LR). a Hydraulic gradient and vertical displacement; $\mathbf{b}$ Seepage water volume and TSS

for the large reservoir due to which a longer life span was recorded. The TSS has increased abruptly before the failure of dam crest for both small and large reservoirs. The vertical displacement was high for the large reservoir case, where the seepage water volume was also high, and the failure for half part of the dam crest was noticed for the large reservoir case.

For the S4568 sample, the TSS value was greater in case of the small-sized reservoir, due to which the vertical displacement was also high, and the failure of dam crest was observed earlier than in the case of the large-sized reservoir (Fig. 8). The initial rate of seepage water volume for the small reservoir was greater, and the cumulative total seepage water volume before the dam failure was greater for the largesized reservoir. For the small reservoir, due to the higher TSS, internal erosion occurred, and the shear strength of the soil decreased, leading to a low hydraulic gradient at the time of failure compared to that observed for a large-sized reservoir.

For the S456 sample, TSS was nearly constant for the large reservoir and rapidly increased at the time of failure, whereas for the small reservoir, TSS slowly increased with fluctuation (Fig. 9). The hydraulic gradient for the small reservoir was less than that for the large reservoir, which was different from other experiments with the S568 sample. Similarly, for the large reservoir, failure hydraulic gradient was highest throughout this study, which may be the effect of the reservoir size. Takaji and Yusuke (2008) reported that physical parameters such as particle density, hydraulic conductivity, and gravel content affect the seepage development in landslide dams and soil slopes, which can be used in this experiment. The seepage rate was nearly the same for large- and small-sized reservoirs, but the total seepage volume was greater for the large-sized reservoir. Horizontal displacement was noticed for a a)

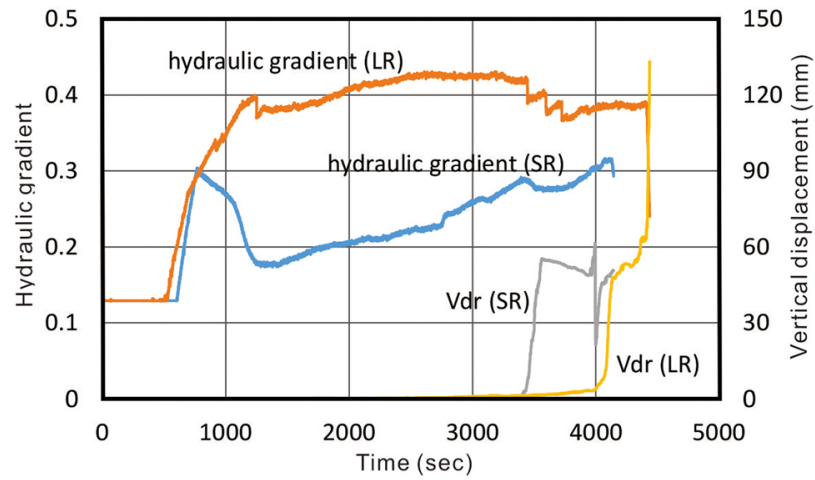

b)

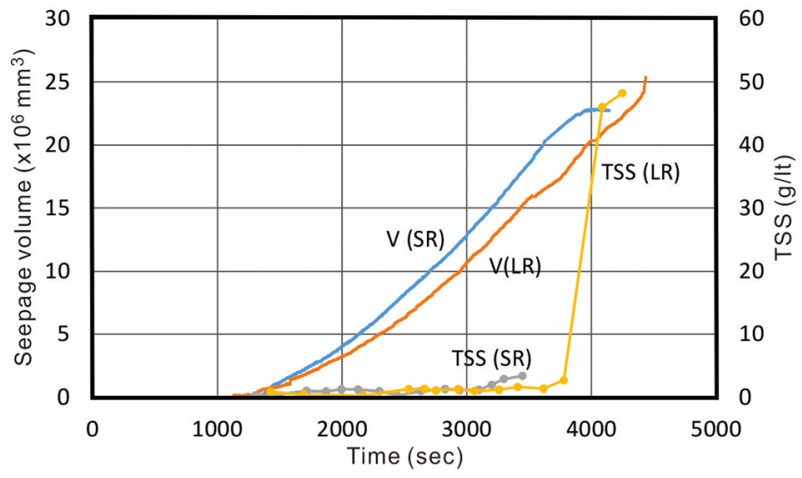

Fig. 9 Time series data of hydraulic gradient, vertical displacement, seepage volume and TSS for the sample S456 at a small reservoir (SR) and large reservoir (LR). a Hydraulic gradient and vertical displacement; $\mathbf{b}$ Seepage volume and TSS 


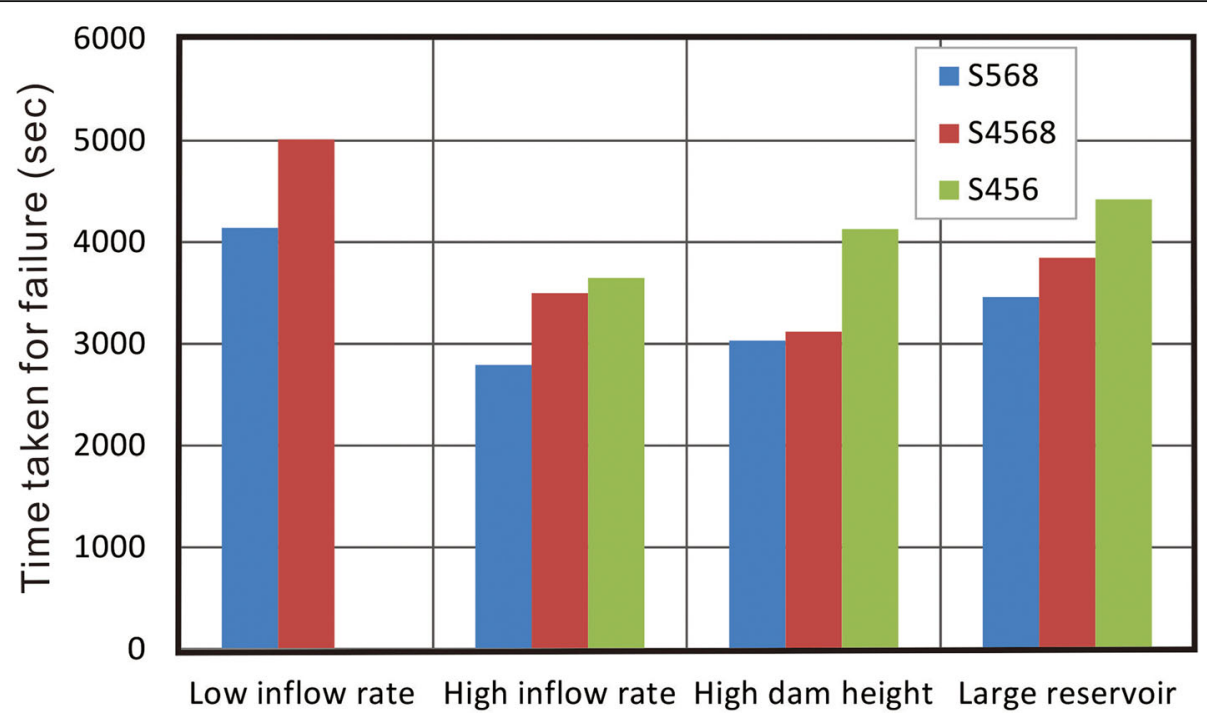

Fig. 10 Time taken for failure of dam crest for different conditions

small reservoir after the failure of the half part of the dam crest; hence, the vertical displacement decreases.

\section{Conclusion}

A series of experiments were performed to investigate the effects of particle size, inflow rate into the reservoir, dam height, and reservoir size on the seepage volume, time of failure, and TSS of for seepage-induced failure of landslide dams using a flume tank. Limit values of hydraulic gradients were determined under different hydro-mechanical and geometrical conditions. Based on the experimental results, the following conclusions are drawn.
1. Experiments conducted on three samples prepared by mixing the silica sand revealed that the time of failure of experiments increases depending on the changes in the percentages of fine and coarser sand. Samples with finer particles exhibited a short dam life span (Fig. 10)

2. At a low inflow rate into the reservoir, the hydraulic gradient to initiate the seepage was less than that at the time of failure (Fig. 4 and Fig. 5). The internal structure was more stable due to the low hydraulic gradient, leading to low TSS and negligible vertical displacement; however, the total seepage volume was high

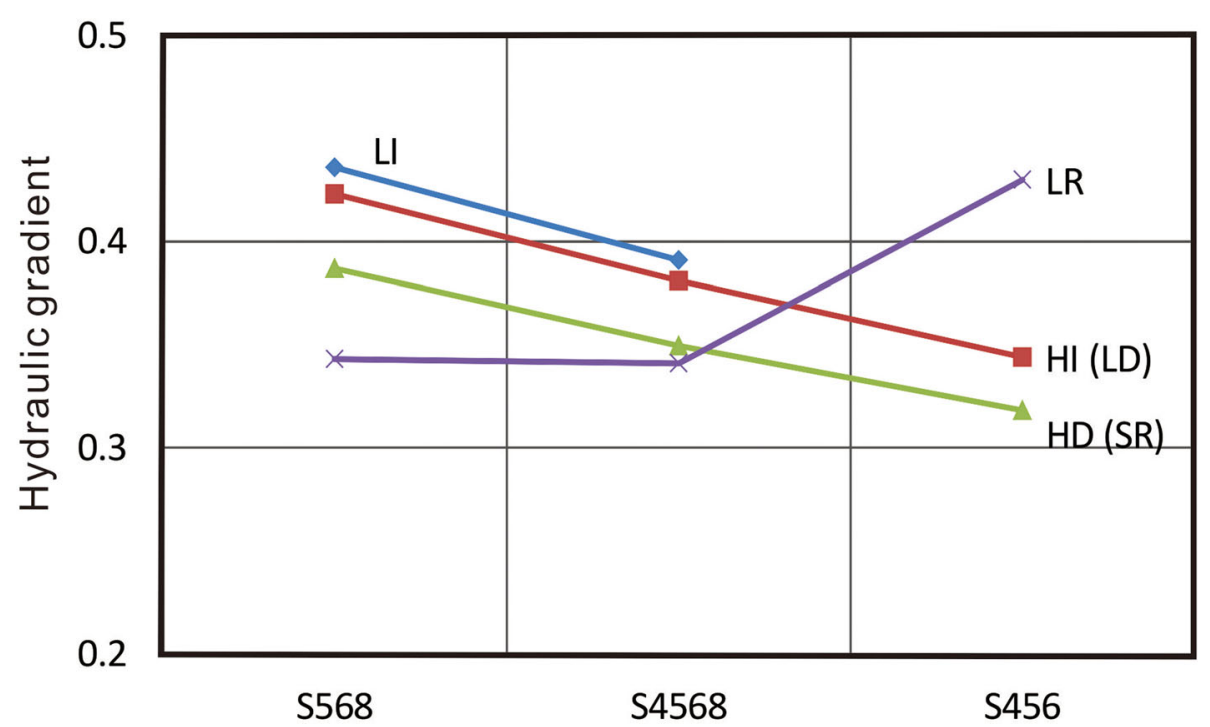

Fig. 11 Maximum hydraulic gradient for low inflow rate (LI), high inflow rate (HI), low dam (LD), high dam (HD), small reservoir (SR) and large reservoir (LR) of three samples 
3. For the sample comprising coarser particles and small coefficient of uniformity may reduce the life span of dam, possibly related to the change in the permeability and effect of the critical hydraulic gradient to initiate the seepage or internal instability

4. With the increase in reservoir volume, the maximum hydraulic gradient exhibited differently as that observed in case of inflow rates and dam height (Fig. 11), and the seepage water volume increased, and TSS decreased with the increase in the reservoir volume.

5. Although there was a continuous process of the hydraulic gradient and seepage and erosion, the hydraulic gradient was predominantly affected by the inflow rate and dam geometry, whereas the total seepage volume, seepage rate, and TSS depended on the particle size of the dam material and reservoir size.

\section{Abbreviations}

TSS: Total suspended solids; PVC: polyvinyl chloride.

\section{Acknowledgments}

The first author would like to express warm gratitude to the Rotary Yoneyama Memorial Foundation and the Izumo South Rotary Club for providing a scholarship for the first author. The authors would also like to thank the anonymous reviewers for reviewing the manuscript.

\section{Authors' contributions}

DP conducted the laboratory work with close coordination with FW. FW provided guidance and support for data analysis and presentation. DP drafted the manuscript, and both authors read and approved the manuscript.

\section{Funding}

None.

\section{Availability of data and materials}

The data sets used and analysed during the current study are available from the corresponding author on reasonable request. All data used in this study were produced in the department of Earth science laboratory of Shimane University.

\section{Competing interests}

The authors declare that they have no competing interests.

Received: 14 November 2019 Accepted: 27 January 2020

\section{Published online: 28 April 2020}

\section{References}

Ahlinhan MF, Koube MB, Adjovi CE (2016) Assessment of the internal instability for granular soils subjected to seepage. J Geosci Environ Protect 4:46-55 Awal R, Nakagawa H, Baba Y, Sharma RH (2007) Numerical and experimental study on landslide dam failure by sliding. Annual J Hydraul Eng JSCE 51:7-12

Awal R, Nakagawa H, Fujita M, Kawaike K, Baba Y, Zhang H (2011) Study on the piping failure of a natural dam. Ann Dis Prev Res Institute Kyoto Univ 54: $539-547$

Brauns J (1985) Stability of layered granular soil under horizontal groundwater flow. In: Proceedings of the 15th international congress on large dams, Lausanne 1985

Budhu M, Gobin R (1996) Slope instability from ground-water seepage. J Hydraul Eng 122(7):415-417

Canuti P. Casagli N, Ermini L (1988) Inventory of landslide dam in the northern Apennine as a model for induced flood hazard forecasting. In: Andah K (ed)
Managing hydro- geological disaster in a vulnerable environment. Grifo Publishers, Perugia, pp 189-202

Casagli N, Ermini L (1999) Geomorphic analysis of landslide dams in the northern Apennine. Trans Jpn Geomorphol Union 20(3):219-249

Casagli N, Ermini L, Rosati G (2003) Determining grain size distribution of material composing landslide dams in the northern Apennines: sampling and processing methods. Eng Geol 69(1):83-89

Chai HJ, Liu HC, Zhang ZY (1995) The catalog of Chinese landslide dam events. J Geol Hazards Environ Preservation 6(4):1-9

Chang DS, Zhang LM, Xu Y, Huang RQ (2011) Field testing of erodibility of two landslide dams triggered by the 12 may Wenchuan earthquake. Landslides 8(3):321-332

Clague JJ, Evans SG (1994) Formation and failure of natural dams in the Canadian cordillera. Geol Survey Canada Bull 464:1-35

Costa JE, Schuster RL (1988) The formation and failure of natural dams. Geol Soc Am Bull 100:1054-1068

Costa JE, Schuster RL (1991) Documented historical landslide dams from around the world. Bull US Geol Surv:1-486. https://pubs.er.usgs.gov/publication/ ofr91239.

Dhungana P, Wang F (2019) The relationship among the premonitory factors of landslide dam failure caused by seepage: an experimental study. Geoenviron Disasters. https://doi.org/10.1186/s40677-019-0135-7

Dunning SA, Rosser NJ, Petley DN, Massey CR (2006) Formation and failure of the Tsatichhu landslide dam, Bhutan. Landslides 3:107-113

Ermini L, Casagli N (2003) Prediction of the behavior of landslide dam using a geomorphological dimensionless index. Earth Surf Proc Land 28(1):31-47

Evans SG, Delaney KB, Hermanns RL, Strom A, Scarascia-Mugnozza G (2011) The formation and behavior of natural and artificial rockslide dams; implications for engineering performance and hazard management. In: Evans SG, Hermanns RL, Strom A (eds) Scarascia-Mugnozza G Natural and artificial rockslide dams. Springer, Berlin Heidelberg, pp 1-75

Fox GA, Felice RG, Midgley TL, Wilson GV, Al-Madhhachi AS (2014) Laboratory soil piping and internal erosion experiments: evaluation of a soil-piping model for low-compacted soils. Earth Surf Proc Land 39(9):1137-1145

Fox GA, Wilson GV, Simon A, Langendoen EJ, Akay O, Fuchs JW (2007) Measuring streambank erosion due to groundwater seepage: correlation to bank pore water pressure, precipitation and stream stage. Earth Surf Proc Land 32(10): 1558-1573

Hanson GJ, Tejral RD, Hunt SL, Temple DM. (2010) Internal erosion and impact of erosion resistance. In Proceedings of the 30th U.S. Society on Dams Annual Meeting and Conference, April 12-16, 2010, Sacramento, California. p. 773784.

Iverson RM, Major JJ (1986) Groundwater seepage vectors and the potential for hillslope failure and debris flow mobilization. Water Resour Res 22(11):15431548

Korup $O$ (2004) Geomorphometric characteristics of New Zealand landslide dams. Eng Geol 73(1):13-35

Lobkovsky AE, Jensen B, Kudrolli A, Rothman DH (2004) Threshold phenomena in erosion driven by subsurface flow. J Geophys Res Earth Surf 109:F04010. https://doi.org/10.1029/2004JF000172

Maknoon M, Mahdi TF (2010) Experimental investigation into embankment external suffusion. Nat Hazards 54(3):749-763

Okeke ACU, Wang F (2016a) Critical hydraulic gradients for seepage induced failure of landslide dams. Geoenviron Dis. https://doi.org/10.1186/s40677-0160043-z

Okeke ACU, Wang F (2016b) Hydromechanical constraints on the piping failure of landslide dams: an experimental investigation. Geoenviron Dis. https://doi. org/10.1186/s40677-016-0038-9

Peng M, Zhan LM (2012) Breaching parameters of landslide dam. Landslides 9: 13-31. https://doi.org/10.1007/s10346-011-0271-y

Richards KS, Reddy KR (2007) Critical appraisal of piping phenomena in earth dams. Bull Eng Geol Environ 66(4):381-402

Rinaldi M, Casagli N (1999) Stability of streambanks formed in partially saturated soils and effects of negative pore-water pressures: the Sieve River (Italy). Geomorphology 26(4):253-277

Rügner H, Schwientek M, Beckingham B, Kuch B, Grathwohl P (2013) Turbidity as a proxy for total suspended solids (TSS) and particle facilitated transport in catchments. Environ Earth Sci 69(2):373-380

Schuster RL (1995) Landslide dams-a worldwide phenomenon. In: Proceedings of the annual symposium of the Japanese landslide society. Kansai Branch, Osaka, pp 1-23 
Schuster RL, Costa JE (1986) A perspective on landslide dam. In: Shuster RL (ed) Landslide dams: Processes, risk, and mitigation. Proceedings of a session in conjunction with the ASCE convention. ASCE (Geotechnical Special Publ no. 3), New York, pp 1-20

Sidle RC, Kitahara H, Terajima T, Nakai Y (1995) Experimental studies on the effects of pipe flow on through flow partitioning. J Hydrol 165(1):207-219

Stefanelli CT, Catani F, Casagli N (2015) Geomorphological investigations on landslide dams. Geoenviron Dis 2(1):21

Stubblefield AP, Reuter JE, Dahlgren RA, Goldman CR (2007) Use of turbidometry to characterize suspended sediment and phosphorus fluxes in the Lake Tahoe basin, California, USA. Hydrol Process 21:281-291. https://doi.org/10. 1002/hyp.6234

Tacconi C, Vilímek V, Emmer A, Catani F (2018) Morphological analysis and features of the landslide dams in the cordillera Blanca. Landslides 15(3):507521

Takaji K, Yusuke F (2008) Effect of particle gradation on seepage failure in granular soils. In: Sekiguchi $\mathrm{H}$ (ed) Proceedings of the 4th international conference on scour and Erosion (ICSE-4), November 5-7, 2008. The Japanese Geotechnical Society, Tokyo, pp 497-504

Uhlir CF (1998) Landslide-dammed lakes: a case study of the Lamabagr and Chanurikharka landslide deposits, Dolakha and Solukhumbu districts, eastern Nepal. J Nepal Geol Soc 18:329-334

Wang F, Dai Z, Okeke CAU, Mitani Y, Yang H (2018) Experimental study to identify premonitory factors of landslide dam failures. Eng Geol 232:123-134

Wilson G (2011) Understanding soil-pipe flow and its role in ephemeral gully erosion. Hydrol Process 25(15):2354-2364

Wilson GV (2009) Mechanisms of ephemeral gully erosion caused by constant flow through a continuous soil-pipe. Earth Surf Proc Land 34(14):1858-1866

Wilson GV, Periketi RK, Fox GA, Dabney SM, Shields FD, Cullum RF (2007) Soil properties controlling seepage erosion contributions to streambank failure. Earth Surf Proc Land 32(3):447-459

Wit JD, Sellmeijer JB, Penning A (1981) Laboratory testing on piping, 517-520. Tenth International Conference on Soil Mechanics and Foundation Engineering, In

Xu Q, Fan XM, Huang RQ, Westen CV (2009) Landslide dams triggered by the Wenchuan earthquake, Sichuan Province, Southwest China. Bull Eng Geol Environ 68(3):373-386

\section{Publisher's Note}

Springer Nature remains neutral with regard to jurisdictional claims in published maps and institutional affiliations.

\section{Submit your manuscript to a SpringerOpen ${ }^{\circ}$ journal and benefit from:}

- Convenient online submission

- Rigorous peer review

- Open access: articles freely available online

- High visibility within the field

- Retaining the copyright to your article

Submit your next manuscript at $\boldsymbol{\nabla}$ springeropen.com 